\title{
Get involved with ACRL \\ Volunteer to serve on a division or section committee
}

A CRL division and section committee volunteers are an integral part of the association. Committee members help shape the organization by advancing its strategic plan and influencing the direction of academic and research librarianship.

If you have been looking for a way to become more involved, ACRL Vice-President/ President-Elect Lisa Janicke Hinchliffe invites you to volunteer for a division or section committee for the 2010-11 term.

\section{The rewards of volunteering}

Volunteers benefit by:

- building ties with academic and research librarians around the country,

- enhancing their leadership abilities through consensus building and project management,

- sharing their experience with colleagues,

- gaining additional expertise about a new area of academic librarianship or updating expertise in a current specialization, and

- advancing the work of the association and the profession.

\section{The appointment process}

Appointments are made at the division and section level. The ACRL vice-president is responsible for committee appointments at the division level for the year he or she serves as president. The ACRL Appointments Committee assists the vice-president in an advisory capacity. The chairs of coordinating committees make appointments to committees linked to each coordinating committee. Section vice-chairs are responsible for committee appointments for the year they will serve as chair. Most committee appoint- ments will be made following the 2010 ALA Midwinter Meeting.

\section{Factors influencing appointment}

Although the emphasis in the appointment process may vary from year to year according to the priorities of the vice-president/ president-elect, coordinating committee chairs, and section vice-chairs, several factors are always considered, including:

- Evidence of prospective committee member's interest and expertise. Have potential volunteers attended the meetings and introduced themselves to the chair? Do they have knowledge and/or previous experience that relates to the work of the committee? Have they indicated their interest on the volunteer form?

- Demographics and composition of committee. A balance is sought with respect to type of library (community college, college, or university), geographic representation, ethnic diversity, and gender. Those who have not had the opportunity to serve on an ACRL committee are encouraged to volunteer.

- Recommendation of the current committee chair. Current committee chairs are asked to suggest prospective members.

The final appointments are the prerogative of the ACRL president-elect, the coordinating committee chairs, and the section vice-chairs.

\section{How to apply}

1. Identify the committees that interest you. ACRL committees and their charges are listed on the ACRL Web site (www.acrl. org, select "Committees and Groups" from the "Committees and Groups" drop-down 
menu). Attend committee meetings at the ALA Midwinter Meeting and Annual Conference to help you decide if their activities interest you. Talk with committee members. Express your interest to the committee chair. Ask about current projects and explain how you might contribute to the work of the committee.

2. Submit a volunteer form. For division-level committees, visit www.ala.org/ala /mgrps/divs/acrl/resources/forms/volunteer. cfm for more detailed instructions. Forms should be submitted by December 1, 2009.

For section committees, complete the online volunteer form at http://www.acrl.org/ volunteer. You will be asked to login using your ALA member ID and the password you created. The form should be completed by February 15, 2010.

3. Volunteer again. If you are not successful in being appointed one year, volunteer again the next year.

Remember that many factors-number of appointments made, number of volunteers for each committee, number of volunteers from your type of library or your geographic area-determine the actual appointment, and these factors change from year to year.

\section{ACRL division-level committee appointments}

ACRL has more than 30 standing committees for which you may volunteer to serve for 2010-11. The committees are listed along with their charges on the ACRL Web site (www. acrl.org, select "Committees and Groups" from the "Committees and Groups" dropdown menu).

In 2005, the ACRL Board of Directors identified structural changes to the association intended to coordinate the work of units throughout the organization, reduce duplicative efforts, and allow the organization to conduct work more quickly and effectively. One such structural change was to link committees that have similar or related missions under the umbrella of a coordinating committee.

Coordinating committees have divisionwide responsibilities to coordinate a broadly defined range of efforts in each committee's respective area throughout ACRL and to organize the efforts into a coherent and effectively implemented set of programs and initiatives that are more closely aligned to the strategic plan. Coordinating committee chairs are responsible for appointing the members of the component committees.

Appointments to ACRL standing committees are made in the spring for terms beginning immediately after the ALA Annual Conference. The Appointments Committee recommends to the president-elect of ACRL the names of members who might fill the vacancies and coordinating committees do the same for their chair. The president-elect and coordinating committee chair make the final appointments for the committees for which they are responsible.

Questions about division-level appointments may be directed to the chair of the Appointments Committee, Beth Woodard, University of Illinois at Urbana-Champaign; e-mail: bswoodar@illinois.edu.

If you have any questions about using the volunteer form, please contact ACRL Program Coordinator Joe Barkley at jbarkley@ala.org or (312) 280-2512.

\section{ACRL section appointments}

ACRL has 17 sections to help members customize their ACRL experience through newsletters, electronic discussion lists, specialized programming, preconferences, recognition, and focused activities. A description of their areas of responsibility is available online at www.ala.org/ala/mgrps/divs/acrl/about /sections/index.cfm.

Section vice-chairs appoint the members of section committees. Most of these appointments are made in the spring for terms beginning immediately after the ALA Annual Conference.

If you would like to be considered for appointment as a chair or member of a section committee, fill out the ACRL volunteer form at www.acrl.org/volunteer by February 15, 2010. If you have questions about the form, please contact ACRL Program Coordinator Adam Burling at aburling@ala.org or (312) 
280-2521. Contact information for the vicechair of each section is below.

African American Studies Librarians Section. Joyce Thornton, Texas A\&M; phone: (979) 862-4232; e-mail: jkthorn@ tamu.edu.

Anthropology and Sociology Section. Jennifer Nason Davis, University of MichiganAnn Arbor; phone: (734) 647-5293; e-mail: jnasond@umich.edu.

Arts Section. Claudia Covert, Rhode Island School of Design; phone: (401) 4546227; e-mail: ccovert@risd.edu.

Asian, African and Middle Eastern Section. Triveni Kuchi, Rutgers University; phone: (732) 445-5733; e-mail: kuchi@rci. rutgers.edu.

College Libraries Section. Christopher Millson-Martula, Lynchburg College; phone: (434) 544-8399; e-mail: millsonmartula@ lynchburg.edu.

Community and Junior College Libraries Section. David Wright, Surry Community College; phone: (336) 386-3252; e-mail: wrightd@surry.edu.
Distance Learning Section. Robin A. Lockerby, National University Library; phone: (858) 541-7945; e-mail: rlock@nu.edu.

Education and Behavioral Sciences Section. Stephanie Davis-Kahl, Illinois Wesleyan University; phone: (309) 556-3010; e-mail: sdaviska@iwu.edu.

Instruction Section. Polly D. BoruffJones, Indiana University-Purdue University Indianapolis; phone: (317) 274-0467; e-mail: pboruffj@iupui.edu.

Law and Political Science Section. Christopher Palazzolo, Emory University; phone: (404) 727-0143; e-mail: cpalazz@emory.edu.

Literatures in English Section. Liorah Anne Golomb, Wichita State University; phone: (316) 978-5077; e-mail: liorah. golomb@wichita.edu.

Rare Books and Manuscripts Section. Henry Raine, New York Historical Society; phone: (212) 485-9257; e-mail: hraine@ nyhistory.org.

Science and Technology Section. Linda Eells, University of Minnesota-St. Paul; phone: (612) 624-4799; e-mail: 1le@umn.edu.

\section{Nominations sought for ACRL vice-president/president-elect}

To paraphrase Walter Lippman, American journalist, "The final test of a leader is that one leaves behind in others the conviction and the will to carry on"(in New York Herald Tribune 14 April 1945).

An organization needs strong leadership to accomplish its goals. ACRL is no exception.

The ACRL Leadership Recruitment and Nominations Committee encourages members to nominate themselves or others to run for the position of ACRL vice president/ president-elect in the 2010 elections.

To nominate an individual or to selfnominate, send the nominee's name and institution to: Patricia Kreitz, Director, Technical Information Services, Stanford University SLAC, 2575 Sand Hill Rd., Menlo Park, CA 94025-7015, e-mail: pkreitz@slac. stanford.edu.

Once nominated, individuals will need to submit a two-page curriculum vita or resume (if self-nominating, you may include these materials with your nomination). The Leadership Recruitment and Nominations Committee will request statements of interest from selected individuals prior to developing a slate of candidates.

The deadline for nominations is November 20, 2009. 
Slavic and East European Section. Sandra Levy, University of Chicago; phone: (773) 702-6463; e-mail: slevy@uchicago. edu.

University Libraries Section. Kim Leeder, Boise State University; phone: (208) 426-1621; e-mail: kimleeder@boisestate.edu.

Western European Studies Section. Brian William Vetruba, Washington University-St. Louis; phone: (314) 935-4824: e-mail: bvetruba@wustl.edu.

Women's Studies Section. Jane Nichols, Oregon State University; phone: (541) 737-7269; e-mail: jane.nichols@oregonstate. edu.

\section{Editorial boards}

ACRL has nine editorial/advisory boards for its publications: ACRLog Advisory Board; Choice Editorial Board; College \& Research Libraries Editorial Board; College $\&$ Research Libraries News Editorial Board; New Publications Advisory Board; Publications in Librarianship Editorial Board; RBM: A Journal of Rare Books, Manuscripts, and Cultural Heritage Editorial Board; REAL Advisory Board; and Resources for College Libraries Editorial Board.

Appointments to editorial boards are made at the ALA Midwinter Meeting for terms that begin immediately after the ALA Annual Conference.

The editors recommend the names of individuals to fill vacancies. The Publications Coordinating Committee approves the recommendation, and the president of ACRL makes the appointment.

If you would like to be considered for appointment to an editorial board, contact the editor of the editorial board early in the fall or indicate your interest on the ACRL online volunteer form.

ACRLog Advisory Board staff liaison: Mary Jane Petrowski, ACRL; phone: (312) 280-2523; e-mail: mpetrowski@ala.org.
CHOICE editor: Irving Rockwood, Choice; phone: (800) 347-6933 x119; e-mail: irockwood@ala-choice.org.

College \& Research Libraries editor: Joseph Branin, King Abdullah University of Science and Technology; e-mail: joseph. branin@kaust.edu.sa.

College \& Research Libraries News editor: David Free, ACRL; phone: (312) 2802517; e-mail: dfree@ala.org.

New Publications Advisory Board staff liaison: Kathryn Deiss, ACRL; phone: (312) 280-2529; e-mail: kdeiss@ala.org.

Publications in Librarianship editor: Craig Gibson,George Mason University; phone: (703) 993-3716; e-mail: jgibson1@ gmu.edu.

RBM: AJournal of Rare Books, Manuscripts, and Cultural Heritage editor: Beth Whittaker, Ohio State University; phone: (614) 247-7463; e-mail: whittaker.50@osu.edu.

REAL Advisory Board staff liaison: Mary Jane Petrowski, ACRL; phone: (312) 280-2523; e-mail: mpetrowski@ala.org.

Resources for College Libraries chair: Brian Coutts, Western Kentucky University; phone: 270-745-6121; e-mail: Brian.Coutts@ wku.edu. 2

("The college library in the 21st century," continued from page 516)

Shill, Harold B., and Shawn Tonner. "Creating a Better Place: Physical Improvements in Academic Libraries, 1995-2002." College and Research Libraries 64:6 (November 2003): 431-66.

—. "Does the Building Still Matter? Usage Patterns in New, Expanded, and Renovated Libraries, 1995-2002." College and Research Libraries 65:2 (March 2004): 123-50. n 